\title{
Produção de híbridos de tomateiro cultivados sob diferentes porcentagens de sombreamento ${ }^{1}$
}

\author{
Bruno da Silva Otoni ${ }^{2}$, Wagner Ferreira da Mota ${ }^{3}$, Gabriel Rodrigues Belfort ${ }^{4}$, Aderson Rogério Soares Silva ${ }^{5}$, \\ Janiele Cássia Barbosa Vieira ${ }^{5}$, Leandro de Souza Rocha ${ }^{5}$
}

\begin{abstract}
RESUMO
A região norte de Minas Gerais é marcada por um verão de alta intensidade luminosa, o que consequentemente inviabiliza o cultivo de algumas hortaliças nessa época. Objetivando avaliar o rendimento agronômico e a qualidade do cultivo do tomateiro sob diferentes níveis de sombreamento, conduziu-se, de novembro 2009 a fevereiro de 2010, um experimento na empresa Qualihort Sementes Ltda, localizada na cidade de Nova Porterinha, Minas Gerais. O delineamento experimental utilizado foi em blocos casualizados em esquema fatorial $2 \times 4$, com 4 repetições, sendo dois híbridos (Dominador e Giovanna) e quatro porcentagens de sombreamento ( $0 \%, 18 \%, 30 \%$ e $50 \%)$. O híbrido Dominador foi superior ao Giovanna em relação a altura da planta, número total de frutos, número de frutos por planta. O sombreamento promoveu aumento linear na altura das plantas. A produtividade total, comercial e altura das plantas foram maiores quando se utilizou 50\% de sombreamento. As diferentes porcentagens de sombreamento não alteraram significativamente as características avaliadas, pH, Sólidos Solúveis Totais (SST), Acidez Total Titulável (ATT) e Relação Sólidos Solúveis/Acidez Titulável (RSA). Observou-se maior valor médio de pH nos frutos do híbrido Dominador, e maior valor médio de SST no 'Giovanna'. O híbrido Dominador e os ambientes sombreados condicionaram melhores desempenhos agronômicos para o tomateiro no Norte de Minas Gerais, com destaque para a tela de 50\% de sombreamento. Porém, o sombreamento das plantas não influenciou a qualidade dos frutos do tomateiro.
\end{abstract}

Palavras-chave: Licopersicon esculentum Mill., intensidade luminosa, ambiente protegido, cultivares.

\section{ABSTRACT}

\section{Production and characterization of two hybrids of tomato grown under different shading levels}

The northern region of Minas Gerais is marked by summers of high light intensity, which prevents the cultivation of some vegetables in this season. To evaluate the agronomic performance and the quality of the tomato cultivation under different shading levels, we conducted in 11/2009 at 02/2010 an experiment in the company Qualihort Seeds Ltd located in the municipality of Nova Porterinha, Minas Gerais. The experiment was arranged in randomized blocks in a $2 \times 4$ factorial design (two hybrids - Dominator and Giovanna - and four shading levels: $0 \%, 18 \%, 30 \%$ and 50\%) with four replications. The hybrid Dominador was superior to the Giovanna in plant height, fruit number and fruit number per plant. The environments with 50 and 30\% shading promoted higher plants. Marketable yield was highest at 50\% shading. The different levels of shading did not significantly alter the traits $\mathrm{pH}$, Total Soluble Solids (TSS), titratable

\footnotetext{
Recebido em 09/11/2010 e aprovado em 21/06/2012.

Parte da dissertação de Mestrado do primeiro autor

2 Engenheiro-Agrônomo, Mestre. Centro de Ciências Exatas e Tecnológicas, Universidade Estadual de Montes Claros, Avenida Reinaldo Viana, 2630, Bico da Pedra, Caixa Postal 91, 39440-000, Janaúba, Minas Gerais, Brasil. bruno_otoni@yahoo.com

${ }^{3}$ Engenheiro-Agrônomo, Doutor. Centro de Ciências Exatas e Tecnológicas, Universidade Estadual de Montes Claros, Avenida Reinaldo Viana, 2630, Bico da Pedra, Caixa Postal 91, 39440-000, Janaúba, Minas Gerais, Brasil. wfmota@yahoocom.br (autor para correspondência).

${ }^{4}$ Engenheiro-Agrônomo, Doutor. Qualihort Sementes LTDA, Perímetro Irrigado do Gorutuba, Lote E, 104, s/n, Zona Rural, 39525-000, Nova Porteirinha, Minas Gerais, Brasil. gabelfort@yahoo.com

${ }_{5}^{5}$ Graduandos em Agronomia. Centro de Ciências Exatas e Tecnológicas, Universidade Estadual de Montes Claros, Avenida Reinaldo Viana, 2630, Bico da Pedra, Caixa Postal 91, 39440-000, Janaúba, Minas Gerais, Brasil. jani_cassia@yahoo.com.br; aderson.rogerio@bol.com.br; leandro.rocha7528@facebook.com
} 
acidity (TA) and soluble solids / acidity (RSA). It was observed a higher average $\mathrm{pH}$ in fruits of Dominador, and higher mean SST in fruits of Giovanna. Shading of 50\% promoted the greater interception of radiation and promoted a higher production, productivity and leaf area index, as well as higher ambient temperature, whereas the relative humidity was higher in the treatment with $30 \%$ shading.

Key words: Licopersicon esculentum Mill, solar radiation, protected environment, cultivars.

\section{INTRODUÇÃO}

O tomateiro é a segunda hortaliça em importância sócio-econômica no mundo, sendo sua produção superada apenas pela batata, e primeira no Brasil, sendo amplamente cultivada para consumo in natura ou industrializada (Filgueira, 2005). O Brasil é o maior produtor da América do Sul, onde seu cultivo estende-se do nordeste ao extremo sul, cabendo à região Sudeste participação expressiva, $36,03 \%$, seguida da região Centro-Oeste $(31,29 \%)$ e Sul (16,33\%). Os estados de Minas Gerais, São Paulo e Paraná foram os maiores produtores em 2010. Minas Gerais destaca-se por apresentar produtividade média mais elevada, 63,64 thä ${ }^{-1}$, em relação à média nacional que foi de 60,74 tha $^{-1}$ (IBGE, 2011).

O tomateiro pode ser cultivado na primavera-verão sob cultivo protegido, pois é uma época de entre safra de produção conferindo melhores preços de comercialização. Entretanto, existem as restrições impostas pelas chuvas, elevadas temperaturas e luminosidades, além da maior incidência de pragas e doenças (Goto, 1995).

Luz, temperatura e umidade relativa são importantes fatores que afetam a produtividade do tomateiro. A luz tem complexa influência no crescimento, desenvolvimento e produção das culturas. Ela é essencial para a primeira etapa da cadeia de fixação do $\mathrm{CO}_{2}$, a fotossíntese, processo no qual é produzida energia bioquímica necessária ao crescimento e produção das culturas (Papadopoulos \& Hao, 1997; Andriolo, 2000). O aumento da irradiância pode elevar a produção de fotoassimilados e sua disponibilidade para o crescimento da planta e produção de frutos. Entretanto, o crescimento e desenvolvimento normal das culturas só ocorrem quando a quantidade de radiação recebida for superior ao limite trófico. Para a maioria das hortaliças, como o tomateiro, esse nível é de aproximadamente $8,4 \mathrm{MJ} \mathrm{m}^{-2} \mathrm{dia}^{-1}$, considerado como nível em que a planta produz o mínimo de fotoassimilados necessários à sua manutenção (Beckmann et al., 2006). A temperatura tem importante função no controle da velocidade das reações químicas celulares, as quais governam o crescimento e desenvolvimento da planta (Cockshull, 1992). A umidade relativa do ar pode afetar a transpiração da planta por interferir na condutância estomática. Indiretamente, pode afetar a turgência dos tecidos alterando processos metabólicos ligados ao crescimento da planta, como por exemplo, a absorção de nutrientes (Andriolo, 2000).

Regiões semi-áridas, como o Norte de Minas Gerais, apresentam, no verão especialmente, nível de radiação luminosa aproximadamente três vezes maior que o limite trófico requerido pela cultura do tomate; este excesso de luminosidade em conjunto com o excesso de chuva e temperaturas elevadas pode causar prejuízos fisiológicos, como a fotorrespiração, fotoinibição, evapotranspiração acelerada, além dos danos indiretos, oferecendo maiores condições para ocorrência de doenças, pragas e plantas daninhas, tudo isto pode condicionar queda na produção e qualidade.

As constantes inovações tecnológicas no setor hortícola sempre procuraram evidenciar soluções para problemas decorrentes da ação das intempéries climáticas e assim maximizar a produtividade das plantas. Essas soluções têm que ser satisfatórias e economicamente viáveis, evitando prejuízos causados por condições adversas do clima como as citadas acima. Uma das soluções tecnológicas encontradas para minimizar esses problemas é a utilização de ambiente protegido com telas plásticas para sombreamento dos cultivos de hortaliças (Manrique, 1993; Andriolo, 2000; Vida et al., 2004), que já é realizado nas regiões Sudeste, Centro-Oeste, Sul e nos estados de Rondônia, Amazonas e Pará. A radiação solar é o principal fator que limita o rendimento das espécies tanto no campo, como em ambiente protegido, especialmente nos meses de inverno e em altas latitudes.

Estudos tem mostrado eficiência no rendimento agronômico e na qualidade de cultivares e híbridos de tomate em cultivo protegido sob sombreamento em relação ao cultivo a céu aberto em outras regiões do Brasil (Radin et al., 2003; Carrijo et al., 2004; Caliman et al., 2005).

No entanto, são escassas as informações sobre a porcentagem de sombreamento ideal para o cultivo do tomateiro, pois, para se obter máxima produtividade, são necessários conhecimento e entendimento dos fatores que afetam a fisiologia e, consequentemente, a produtividade das plantas. Desta forma, objetivou-se com o presente trabalho avaliar o cultivo e a produção de dois híbridos de tomateiro sob quatro porcentagens de sombreamento. 


\section{MATERIAL E MÉTODOS}

O experimento foi conduzido na empresa Qualihort Sementes Ltda, localizada no município de Nova Porterinha MG, apresentando latitude 15\%48'09" e longitude 4318'32", com altitude de $533 \mathrm{~m}$. O clima, segundo Köppen, do tipo AW (tropical chuvoso, savana com inverno seco), com médias anuais de precipitaçao de $900 \mathrm{~mm}$ e a temperatura média anual é de $24^{\circ} \mathrm{C}$, sendo a média de verão $32^{\circ} \mathrm{C}$, alcançando maxima de $38^{\circ} \mathrm{C}$. O experimento ocorreu durante os meses de novembro 2009 à fevereiro de 2010, em solo classificado como Neossolo Flúvico (Embrapa, 1999). A amostragem do solo, na profundidade de $0-20 \mathrm{~cm}$, revelou os seguintes resultados: $\mathrm{pH}=7,0 ; \mathrm{P}=110 \mathrm{mg} \mathrm{dm}^{-3}$; $\mathrm{K}=234 \mathrm{mg} \mathrm{dm}^{-3} ; \mathrm{Na}=0,1 \mathrm{cmol}_{\mathrm{c}} \mathrm{dm}^{-3} ; \mathrm{Ca}=4,5 \mathrm{cmol}_{\mathrm{c}} \mathrm{dm}^{-3}$; $\mathrm{Mg}=3,3 \mathrm{cmol}_{\mathrm{c}} \mathrm{dm}^{-3} ; \mathrm{Al}=0 \mathrm{cmol}_{\mathrm{c}} \mathrm{dm}^{-3} ; \mathrm{H}+\mathrm{Al}=8,4 \mathrm{cmol}_{\mathrm{c}} \mathrm{dm}^{-3}$; $\mathrm{SB}=8,8 \mathrm{cmol}_{\mathrm{c}} \mathrm{dm}^{-3} ; \mathrm{t}=7,5 \mathrm{cmol}_{\mathrm{c}} \mathrm{dm}^{-3} ; \mathrm{T}=16,1 \mathrm{cmol}_{\mathrm{c}} \mathrm{dm}^{-3}$; $\mathrm{V}=85 \% ; \mathrm{m}=9 \% ; \mathrm{B}=0,8 \mathrm{mg} \mathrm{dm}^{-3} ; \mathrm{Cu}=2,1 \mathrm{mg} \mathrm{dm}^{-3} ; \mathrm{Fe}=56,8$ $\mathrm{mg} \mathrm{dm}^{-3} ; \mathrm{Mn}=43,5 \mathrm{mg} \mathrm{dm}^{-3} ; \mathrm{Zn} ; 5,2 \mathrm{mg} \mathrm{dm}^{-3}$.

Para o preparo do solo foram realizadas gradagem, nivelamento e sulcamento. A adubação química foi realizada de acordo com a análise do solo (Ribeiro et al., 1999). Os fertilizantes utilizados e as respectivas quantidades foram: super fosfato simples (SS) $\left(2000 \mathrm{~kg} \mathrm{ha}^{-1}\right)$, cloreto de potássio (CP) (1034 $\left.\mathrm{kg} \mathrm{ha}^{-1}\right)$ e sulfato de amônio (SA) $\left(1500 \mathrm{~kg} \mathrm{ha}^{-1}\right)$. No plantio, foram aplicados $1400 \mathrm{~kg} \mathrm{ha}^{-1}$, $103,4 \mathrm{~kg} \mathrm{ha}^{-1}$ e $150 \mathrm{~kg} \mathrm{ha}^{-1} \mathrm{de}$ SS, CP e SA, respectivamente. O restante, ou seja, $600 \mathrm{~kg} \mathrm{ha}^{-1}$ de SS foi aplicado aos 15 dias após o transplantio. Já os 930,6 kg ha-1 e $1350 \mathrm{~kg}$ $\mathrm{ha}^{-1}$ de CP e SA foram parcelados em seis adubações de cobertura, iniciadas aos 15 dias após o transplantio e repetidas em intervalos de 15 dias . Durante a frutificação foi realizada aplicação semanal de cloreto de cálcio na concentração de $6 \mathrm{~g} \mathrm{~L}^{-1}$, via foliar. Os micronutrientes foram aplicados via foliar, utilizando-se produto comercial Mastermins.

O delineamento experimental utilizado foi em blocos casualizados, no arranjo fatorial 2 x 4, sendo: 2 híbridos de tomate (Giovanna e Dominador) x 4 porcentagens de sombreamento $(0 \%, 18 \%, 30 \%$, e $50 \%)$, com quatro repetições. A parcela foi constituída por quatro linhas com cinco plantas, totalizando 20 plantas, no espaçamento de 1,0 x 0,5 m. Foram consideradas úteis, para avaliação, as seis plantas centrais, ou seja, $3 \mathrm{~m}^{2}$ de área útil. Foram avaliadas características agronômicas, de qualidade de frutos e de clima.

Os sombreamentos foram constituídos por telas de sombreamento preta, fabricadas com fio polietileno $100 \%$ virgem. Foram estudados dois híbridos de tomate tipo salada, sendo o Dominador F1; hábito de crescimento indeterminado, alto vigor, bom enfolhamento, frutos firmes e de excelente coloração e formato, alta resistência ao TYLCV (Geminivirus), ciclo 120 dias. O outro cultivar foi o
Giovanna F1, hábito de crescimento indeterminado, alto vigor e enfolhamento, fruto tipo salada, com alta qualidade e excelente pós-colheita, bom padrão de frutos, pencas de floração definida, boa tolerância a rachadura e ciclo 110 dias.

A semeadura foi realizada em 15/10/2009, em bandejas de poliestireno expandido com 128 celulas, utilizando-se o substrato comercial Plantmax e uma semente por célula. As bandejas foram colocadas em casa de vegetação ou ambiente protegido até o dia do transplante em 02/12/ 2009. O transplantio das mudas ocorreu quando as plantas apresentavam de quatro a cinco folhas definitivas, colocando-se uma muda por cova. O sistema de irrigação adotado foi o de gotejamento, com emisores espaçados de $0,2 \mathrm{~m}$, sendo o seu manejo realizado com base nas leituras diárias de evaporação obtidas no tanque classe A, aplicando-se uma lâmina de 742,50 mm, em turno de rega de dois dias

O tutoramento foi feito verticalmente com bambus de $2 \mathrm{~m}$ de altura, fixados próximo de cada planta, sendo estas amarradas nos bambus por meio de cordões. Durante o crescimento e desenvolvimento, as plantas foram desbrotadas sistematicamente até atingirem o $6^{\circ}$ cacho, quando houve a poda apical. Foram realizadas quatro capinas com o objetivo de manter a cultura livre de competição com as plantas daninhas. O controle fitossanitário foi realizado aos oito dias após o transplantio (DAT) com

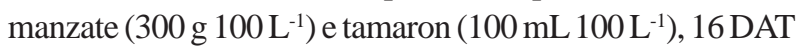

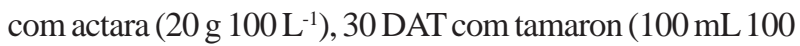

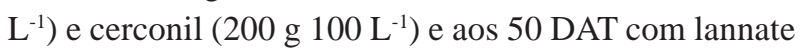
$\left(100 \mathrm{~mL} 100 \mathrm{~L}^{-1}\right)$ e ridomil $\left(300 \mathrm{~mL} 100 \mathrm{~L}^{-1}\right)$ com base na ocorrência de pragas e doenças.

Foram avaliadas características agronômicas, de qualidade de frutos e de clima.

\section{Características agronômicas:}

Produtividade total: os frutos foram colhidos, semanalmente, quando os ápices apresentavam coloração avermelhada, sendo separados em sem e com defeitos (danificados por insetos, pelo sol e danos fisiológicos como deficiência de cálcio). Após a soma de todos os frutos, em todas as colheitas na área útil, fez-se a transformação para 1,0 ha.

Produtividade de frutos comerciais e não comerciais: a produtividade de frutos comercial foi obtida pelo somatório das classes grande e médio sem defeitos e para os não comerciais consideraram-se os frutos miúdos, com diâmetro transversal menor que $50 \mathrm{~mm}$, conforme Portaria do Ministério da Agricultura, Abastecimento e Reforma Agrária no 553, de 30/08/1995 (BRASIL, 1995).

Altura da planta (m): Após a poda apical: medição realizada no caule, a partir do colo até o ápice da planta por meio de uma trena. 
Número médio de frutos por planta: obtido pelo somatório dos frutos colhidos na área útil de cada parcela, sendo esse total dividido pelo número de plantas úteis.

Número total de frutos: foi obtido pelo somatório de frutos colhidos nas plantas na área útil.

Índice de Área Foliar (IAF): foi obtido com o auxilio do medidor de radiação solar accuPAR. A leitura foi obtida após a introdução do aparelho no meio do dossel da planta.

\section{Características de qualidade:}

$\mathrm{pH}$ : foi obtido diretamente por intermédio de pHmetro, marca Digmed, modelo DM-20, após extração e homogeneização do suco dos frutos de cada unidade experimental.

Sólidos Solúveis Totais (SST): a determinação dos sólidos solúveis totais foi feita por refratometria, utilizando-se um refratômetro de campo da marca Atago, modelo $\mathrm{N}-1 \alpha$, com leitura na faixa de 0 a $95^{\circ}$ Brix e os resultados foram expressos em ${ }^{\circ}$ Brix.

Acidez Total Titulável (ATT): determinada por meio da titulação de $10 \mathrm{~mL}$ de suco homogeneizado com $90 \mathrm{~mL}$ de água destilada. Utilizou-se como titulante solução de NAOH 0,2 mol.L $\mathrm{L}^{-1}$ adicionando à amostra três gotas de fenolftaleína a $1 \%$ como indicador, conforme normas da AOAC (1992). Os resultados foram expressos em g de ácido cítrico por $100 \mathrm{~g}$ de suco.

Relação Sólidos Solúveis / Acidez Titulável: a relação foi obtida dividindo-se a percentagem de sólidos solúveis pela acidez titulável.

\section{Características de clima:}

Temperatura e Umidade Relativa: foram avaliadas com o auxílio do Termo Higrômetro (Homie mode 894), a 1,30 m do solo, as leituras foram realizadas três vezes por semana sempre no mesmo horário, ou seja, entre 12:00 às 13:30 h.

Radiação: foi obtida com o auxilio do medidor de radiação solar accuPAR, acima e no meio do dossel da planta, sendo as leituras realizadas três vezes por semana, sempre no mesmo horário: 12:00 às 13:30 h.

Os dados obtidos foram submetidos à análise de variância. As médias dos fatores qualitativos foram comparadas pelo teste de Tukey a 5\% de probabilidade. Para os fatores quantitativos, os modelos de regressão foram escolhidos com base na significância dos coeficientes de regressão, utilizando-se o teste t de Student a 5\% de probabilidade, no coeficiente de determinação e no potencial para explicar o fenômeno biológico. As análises estatísticas foram efetuadas com o auxílio do programa SAEG (2007).

\section{RESULTADOS E DISCUSSÃO}

Houve efeito isolado para os fatores híbridos e sombreamento para as características: altura das plantas, número médio de frutos por planta, número total de fru- tos, produtividades comercial, não comercial e total. Verificou-se superioridade do híbrido Dominador sobre o híbrido Giovanna, para as características altura das plantas, número total de frutos, produtividades comercial e total, mas para número de frutos por planta e produtividade de frutos não comerciais não houve diferença entre híbridos (Tabela 1).

Houve efeito significativo de porcentagens de sombreamento, para todas as características agronômicas avaliadas (Figura 1). Quanto às interações, híbridos e porcentagens de sombreamento, não se verificou efeito significativo para as características avaliadas.

O híbrido Dominador foi superior ao Giovanna para altura da planta e número total de frutos. Esses resultados, provavelmente, condicionaram maiores produtividades de frutos comerciais $\left(27,11 \mathrm{t} \mathrm{ha}^{-1}\right)$ e total $\left(35,96 \mathrm{t} \mathrm{ha}^{-1}\right)$. Não houve diferenças entre híbridos para número médio de frutos por planta e produtividade de frutos não comerciais (Tabela 1). No entanto, as médias de produtividades observadas no presente trabalho foram muito inferiores às médias brasileira e mineira, ou seja, 60,74 t ha ${ }^{-1}$ e 63,64 t $\mathrm{ha}^{-1}$ (IBGE, 2011). Contribuíram para isso alguns fatores como carência de informações sobre manejo dos híbridos no semi árido, como espaçamento, $\mathrm{n}^{\circ}$ de cachos, podas etc, e principalmente a elevada incidência de doenças e pragas, em função das elevadas temperaturas e umidades relativas, típicas do verão chuvoso, período pouco recomendado para cultivo do tomateiro.

A altura das plantas aumentou linearmente, sendo maior no sombreamento de 50\%, com 1,66 m, provavelmente, está relacionada à maior redução de luminosidade o que pode ter condicionado certo grau de estiolamento da planta (Figura 1). A luminosidade influenciou na frutificação, ou seja, o número total de frutos e número médio de frutos por planta variaram em função das porcentagens de sombreamento estudadas, obtendo-se valores máximos de 25,03 frutos e 6,18 frutos por planta, obtidos com $13,4 \%$ e $25,4 \%$ de sombreamento, respectivamente (Figura 1). O tomateiro precisa de $0,85 \mathrm{MJ} \cdot \mathrm{m}^{-2} \cdot \mathrm{dia}^{-1} \mathrm{de}$ energia luminosa para florescer (Andriolo, 2000). Entretanto, na região do Norte de Minas Gerais, percebe-se que os valores máximos de frutificação foram alcançados com maiores níveis de energia luminosa, ou seja,

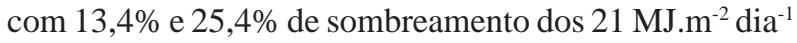
de energia luminosa que ocorrem na primavera verão nessa região (Andriolo, 2000).

A maior altura das plantas sob sombreamento foi acompanhada de aumento linear significativo na produtividade comercial e total em relação à testemunha (Figura 1). Entretanto, a produtividade não comercial se elevou de maneira quadrática até $34,38 \%$ de sombreamento, atingindo $12,83 \mathrm{t} \mathrm{ha}^{-1}$, com posterior redução, atingindo 10,83 $\mathrm{t} \mathrm{ha}^{-1}$ a $50 \%$ de sombreamento. 
Tabela 1. Altura da planta (ALP), número médio de frutos por planta (NFP), número total frutos (NTF), produtividade comercial (PRFC), produtividade não comercial (PRFNC) e produtividade total (PDTT) de dois híbridos de tomate

\begin{tabular}{llllccc}
\hline Híbridos & $\boldsymbol{A L P}(\boldsymbol{m})$ & $\boldsymbol{N F P}$ & $\begin{array}{c}\boldsymbol{N T F} \\
\left(\boldsymbol{t} \boldsymbol{h a}^{-1}\right)\end{array}$ & $\begin{array}{c}\boldsymbol{P R F C} \\
\left(\boldsymbol{t} \boldsymbol{h a}^{-1}\right)\end{array}$ & $\begin{array}{r}\boldsymbol{P R F N C} \\
\left(\boldsymbol{t} \boldsymbol{h a}^{-1}\right)\end{array}$ & $\boldsymbol{P D T T}$ \\
\hline Dominador & $1,62 \mathrm{~A}$ & $6,02 \mathrm{~A}$ & $24,11 \mathrm{~A}$ & $27,11 \mathrm{~A}$ & $9,19 \mathrm{~A}$ & $35,96 \mathrm{~A}$ \\
Giovanna & $1,25 \mathrm{~B}$ & $4,23 \mathrm{~A}$ & $15,93 \mathrm{~B}$ & $8,70 \mathrm{~B}$ & $9,30 \mathrm{~A}$ & $16,84 \mathrm{~B}$ \\
Média & 1,43 & 5,13 & 20,02 & 17,91 & 9,25 & 26,40 \\
\hline C.V. $(\%)$ & 6,69 & 48,02 & 50,86 & 50,15 & 45,62 & 57,23 \\
\hline
\end{tabular}

*Médias seguidas da mesma letra na coluna não diferem entre si pelo teste de Tukey ao nível de 5\% de probabilidade.
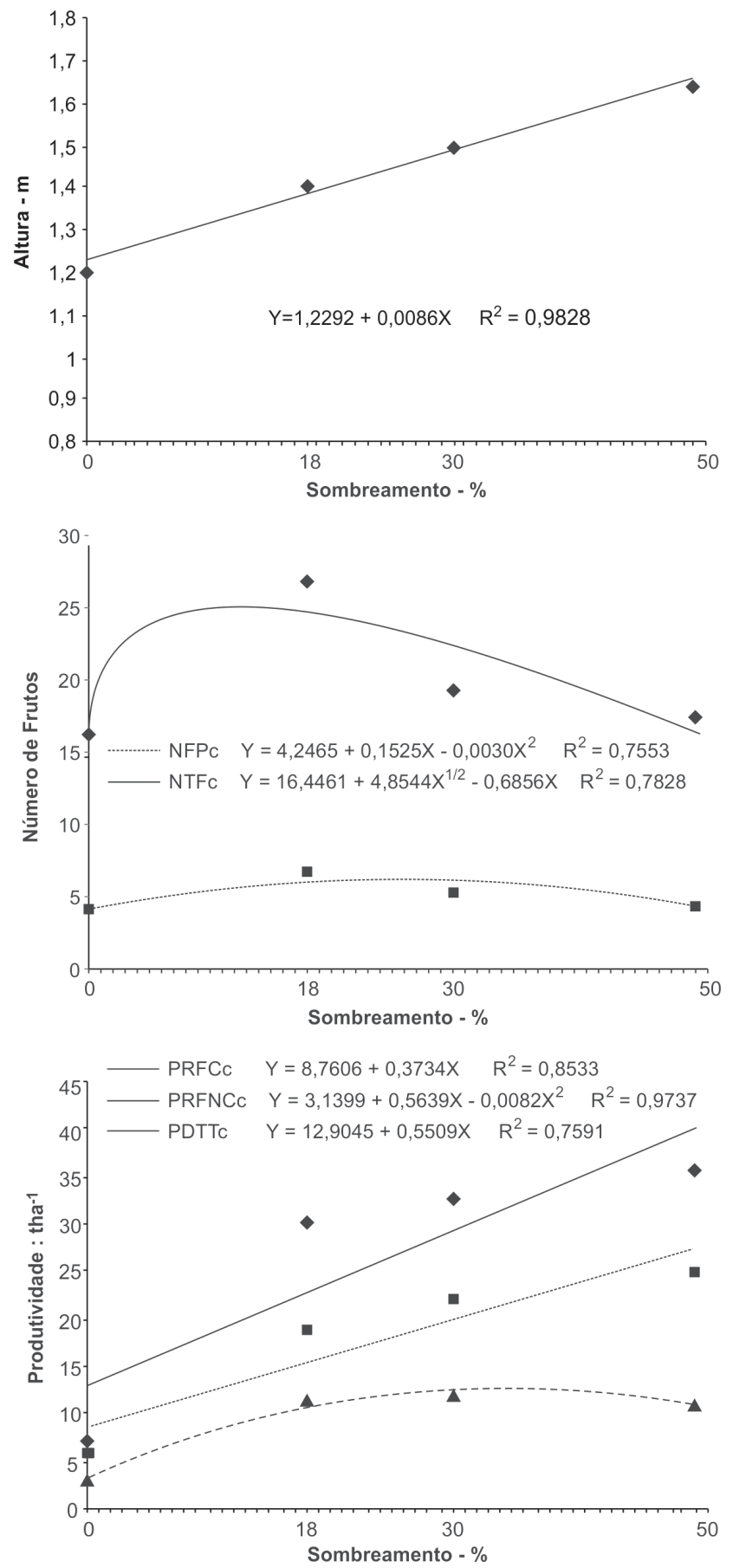

Figura 1. Altura da planta, número médio de frutos por planta (NFPc), número total frutos (NTFc), produtividade comercial (PRFCc), produtividade não comercial (PRFNCc) e produtividade total (PDTTc) de híbridos de tomate em função das porcentagens de sombreamento das plantas.

Rev. Ceres, Viçosa, v. 59, n.6, p. 816-825, nov/dez, 2012 
A Figura 2 mostra a distribuição da radiação acima e abaixo do dossel, para os híbridos Giovanna e Dominador, sob os diferentes porcentagens de sombreamento. Verifica-se que o nível de $50 \%$ proporcionou maior interceptação da radiação, apresentando média de $406,4 \mathrm{~W} / \mathrm{m}^{2}$ de radiação sob o dossel das plantas, sendo que os sombreamentos de $30 \%, 18 \%$ e $0 \%$ apresentaram 666,55 W/m², 927 $\mathrm{W} / \mathrm{m}^{2}$ e $1278,22 \mathrm{~W} / \mathrm{m}^{2}$, respectivamente. Com relação à radiação abaixo do dossel, o ambiente com $50 \%$ de sombreamento registrou menor valor de radiação, apresentando média de $130 \mathrm{~W} / \mathrm{m}^{2}$ havendo pouca diferença entre os híbridos. Observa-se que estes dados refletem diretamente sobre algumas características avaliadas como produtividade total de frutos, altura de plantas, e produtividade de frutos não comerciais. Segundo Andriolo (2000) quando a radiação solar é excessivamente elevada, pode haver aumento na taxa transpiratória da planta resultando em fechamento estomático e diminuição da fotossíntese.

As plantas conduzidas, a céu aberto, apresentaram menor crescimento e consequentemente menores produtividades. A maior radiação solar, ocorrida com $0 \%$ de sombreamento (Figura 2), possivelmente, levou a planta a reduzir a fotossíntese, o que pode ser favorecido por diversos fatores como diminuir a assimilação de $\mathrm{CO}_{2}$ através da fotossíntese, devido a um processo conhecido como fotoinibição (Taiz \& Zeiger, 2004). Por outro lado, a redução da radiação com a utilização de telas de sombreamento minimizou os efeitos extremos da radiação, resultando em aumento da produção.

Ao longo do experimento a temperatura média diária sob a cobertura de $50 \%$ de sombreamento foi maior que nos sombreamentos de $30 \%, 18 \%$ e $0 \%$, sendo que todos os ambientes cobertos apresentaram temperatura maior que a céu aberto (Figura 3). Isso ocorre devido à fraca ação do vento no interior dos ambientes protegidos. Resultados semelhantes foram encontrados por Pereira (2002) estudando a influencia de materiais de cobertura com diferentes níveis de perfuração comparativamente ao cultivo a céu aberto.

A umidade relativa do ar nos ambientes sombreados foi superior à do ambiente a céu aberto (Figura 4). De acordo com Papadopoulos \& Hao (1997), a alta umidade relativa do ar favorece a expansão da folha do tomateiro. Assim o desempenho das plantas nos ambientes com $30 \%$

A
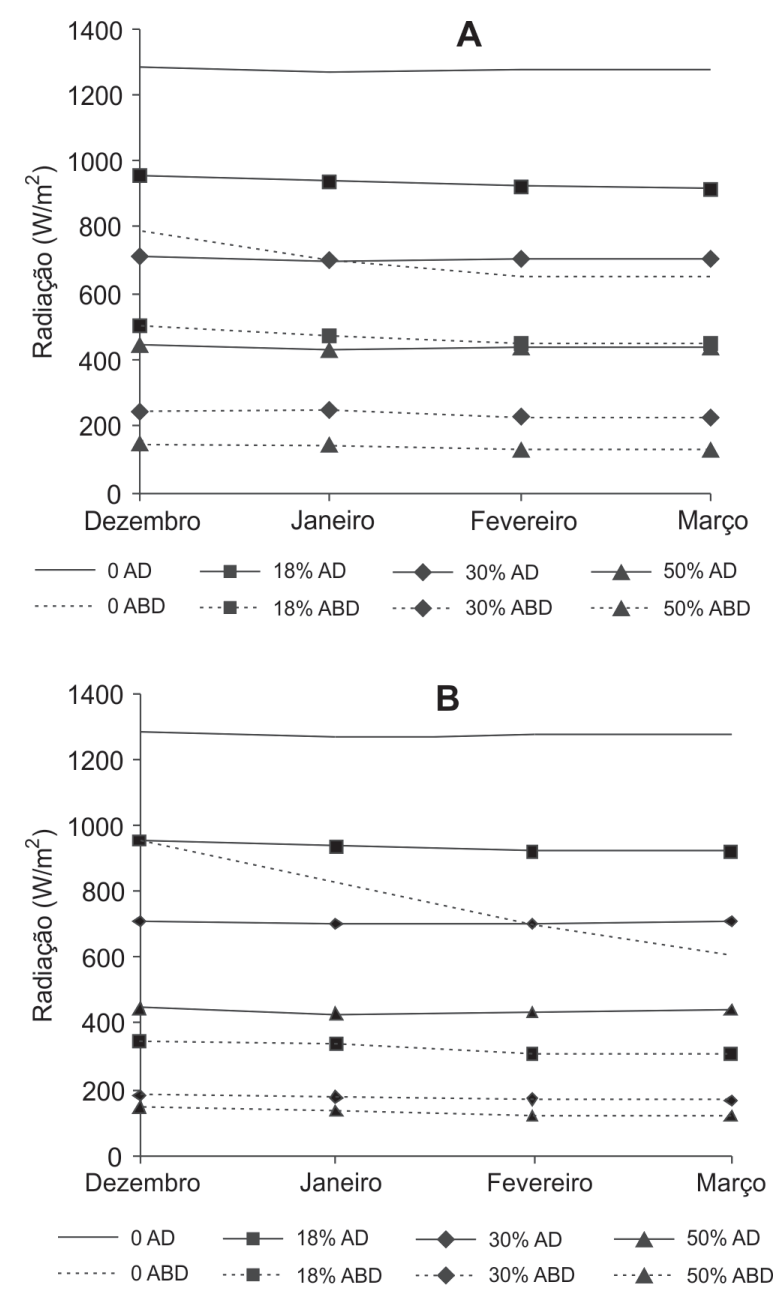

Figura 2. Radiação média registrada acima (AD) e abaixo (ABD) do dossel, em plantas de tomate dos híbridos Giovanna (A) e Dominador (B), durante a condução do experimento nos ambientes com 0, 18, 30 e $50 \%$ de sombreamento. 
e $50 \%$ de sombreamento pode ter favorecido o índice de área foliar.

Verificou-se, de maneira geral, que as características de produção, estimadas principalmente pela produtividade comercial (8,76 tha-1, a céu aberto, a 27,43 t ha-1 a 50\% de sombra) e total (12,90 tha-1, a céu aberto, a 40,45 $\mathrm{t} \mathrm{ha}^{-1}$, a $50 \%$ de sombra), foram baixas, mesmo nos tratamentos mais produtivos. Produtividades acima de $120 \mathrm{t} \mathrm{ha}^{-1} \mathrm{em}$ cultivo protegido com híbridos de tomate são, normalmente, alcançados em ambiente protegido (Gualberto et al., 2002), no entanto, como o experimento foi conduzido na primavera-verão, temperaturas e umidades relativa foram elevados (Figuras 3 e 4) o que condicionou elevada incidência de doenças.

Caliman et al. (2005), verificaram que a temperatura do ar em ambiente protegido foi superior à do campo e afirmaram que esta característica de clima afeta diversos pro- cessos biológicos da planta, em especial o crescimento e produção. As altas temperatura e umidade relativa nesta época do ano condicionaram alta incidência de doenças e pragas condicionando desfolha e redução da área e fotossinteticamente ativa, resultando em menor produção no tomateiro. Isso normalmente acontece com esta cultura. Nunes \& Leal (2001) e Caliman et al. (2005) também verificaram quebra de produção em campo e ambiente protegido na primavera-verão em função da maior incidência de pragas e doenças.

De maneira geral, os ambientes sombreados proporcionaram melhor desempenho dos híbridos avaliados. O sombreamento de $50 \%$ apresentou maior crescimento das plantas e produção. A absorção da radiação pelas culturas depende do seu índice de área foliar, posição solar, geometria e tamanho da folha, ângulo de distribuição, idade, arranjo das plantas, época do ano e nebulosidade

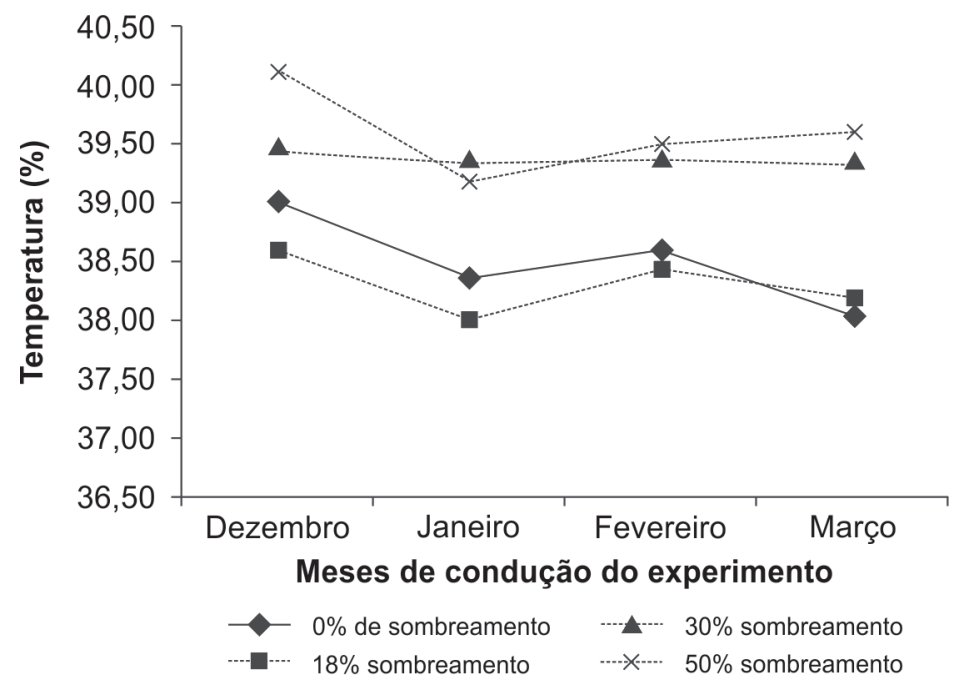

Figura 3. Temperatura média durante a condução do experimento nos ambientes $0,18,30$ e $50 \%$ de sombreamento.

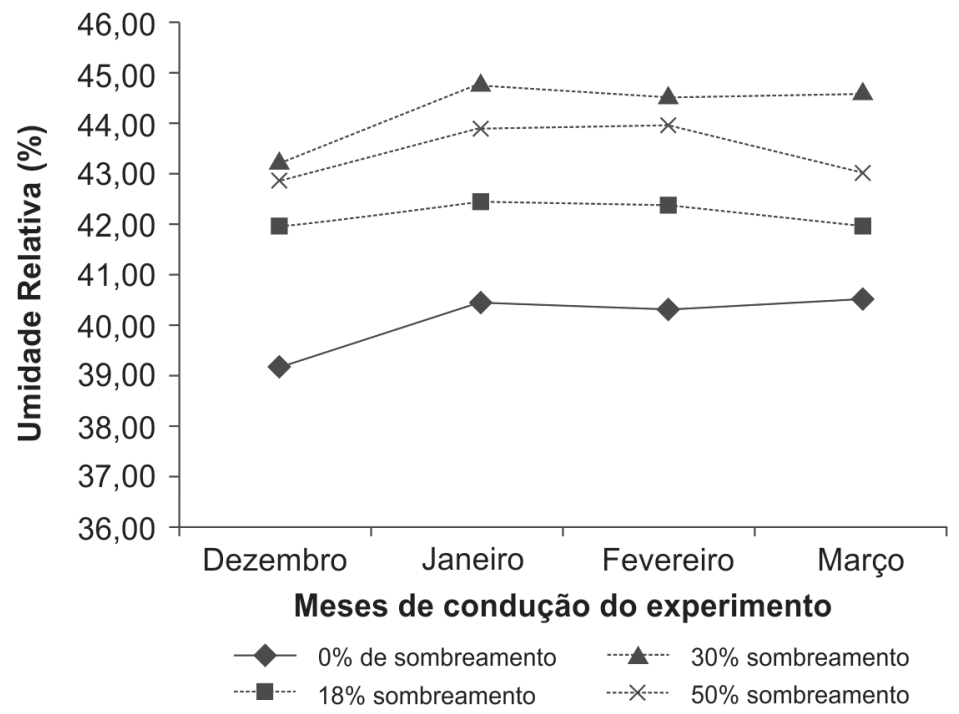

Figura 4. Umidade Relativa média do ar, durante a condução do experimento nos ambientes $0,18,30$ e $50 \%$ de sombreamento. 
(Varlet-Grancher et al., 1989) e ainda da espécie cultivada, das condições meteorológicas e de práticas de manejo da cultura.

A alta incidência de radiação solar registrada no período de condução do experimento proporcionou mudanças nos aspectos fisiológicos da cultura do tomateiro, reduzindo a eficiência fotossintética das plantas, interferindo negativamente em algumas características avaliadas a pleno sol como a altura da planta, e produtividades comercial e total.

O híbrido Dominador apresentou maior índice de área foliar (IAF) em relação ao híbrido Giovanna, devido ao melhor enfolhamento que é uma característica do genótipo. Em relação às porcentagens de sombreamento, observase maior IAF no ambiente de 50\% (Figura 5). Este ambiente, juntamente com o de $30 \%$, apresentou melhor eficiência do uso da radiação, conduzindo a maior produtividade de frutos comerciais. Já no ambiente sem sombreamento, a campo, obteve-se menor IAF, pois neste ambiente a eficiência do uso da radiação é baixa, sendo que, a maioria das folhas está sujeita à saturação fotossintética por radiação (Taiz \& Zeiger, 2004).
O híbrido Dominador apresentou maiores valores de pH $(4,17)$, enquanto o Giovanna maior valor de sólidos solúveis (4,58 Bix). Para acidez titulável e relação sólidos solúveis/acidez titulável, não foram observadas diferenças entre os híbridos Giovanna e Dominador (Tabela 2).

As porcentagens de sombreamento utilizadas não alteraram significativamente os valores de $\mathrm{pH}$, acidez titulável, sólidos solúveis totais e relação sólidos solúveis totais/acidez titulável.

Desta forma, verificou-se que a intensidade de luz não influenciou na qualidade dos frutos de tomate, ou seja, sombreando ou não as plantas, os fotoassimilados (açúcares) produzidos nas folhas durante o processo de fotossíntese são destinados preferencialmente para o aumento na massa de matéria fresca e do número de frutos por planta nesses híbridos testados.

Fontes et al. (2004), trabalhando com tomate (híbrido Carmen) em cultivo protegido com filme plástico de polietileno, não verificaram diferença entre tratamentos para as características de qualidade: $\mathrm{pH}$, vitamina $\mathrm{C}$, sólidos solúveis totais e acidez titulável. O teor de sólidos
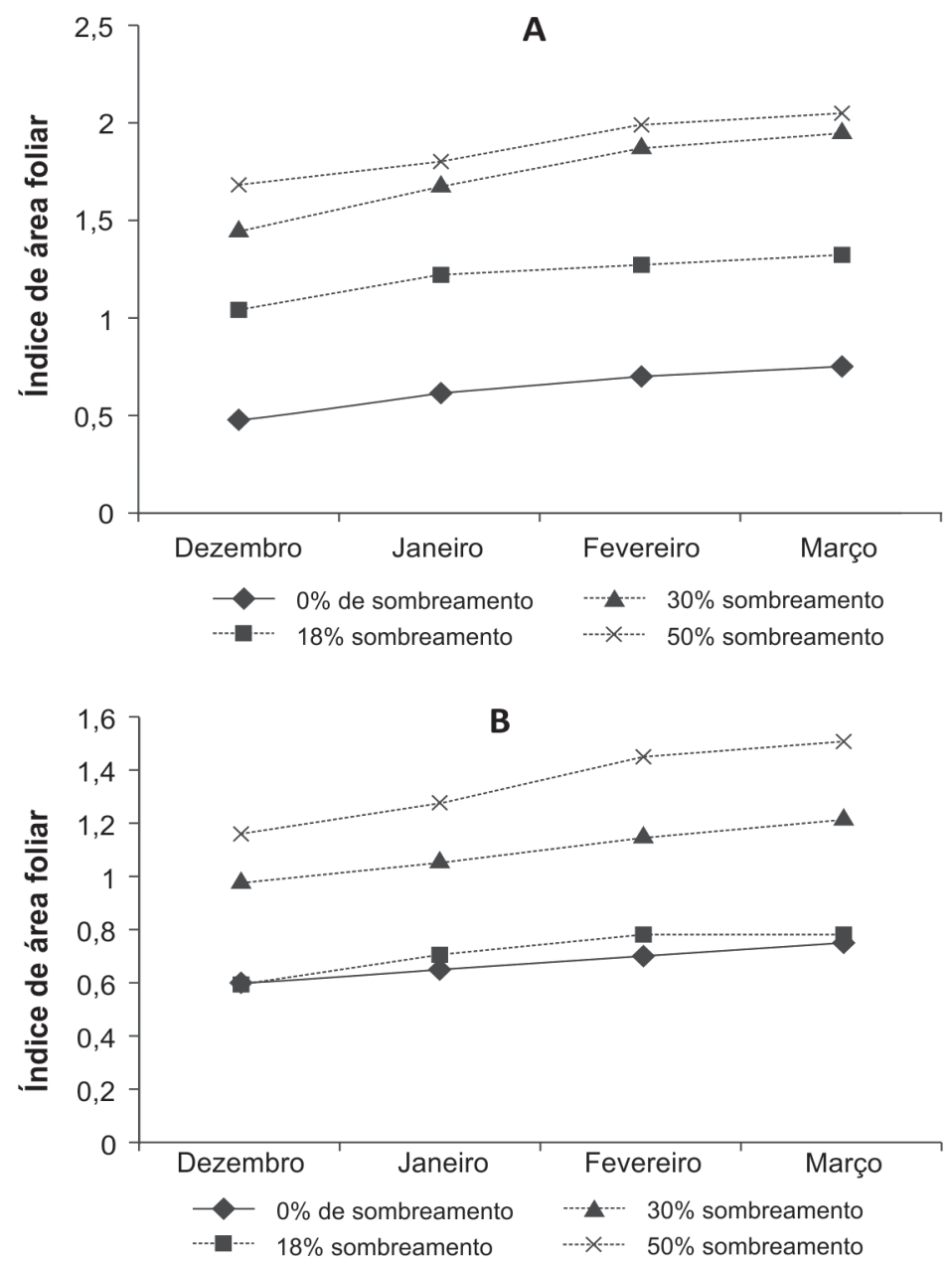

Figura 5. Índice de área foliar dos híbridos de tomate Dominador (A) e Giovanna (B) cultivado em ambientes com 0, 18, 30 e 50\% de sombreamento. 
Tabela 2. pH, acidez titulável (Acidez), sólidos solúveis totais (SST) e relação sólidos solúveis/acidez titulável (RSSA) em dois híbridos de tomate em função das porcentagens de sombreamento das plantas

\begin{tabular}{lcccc}
\hline Híbridos & $\mathbf{p H}$ & Acidez $(\mathbf{g} / \mathbf{1 0 0 g})$ & SST $\left({ }^{\circ}\right.$ Brix $)$ & RSSA \\
\hline Dominador & $4,17 \mathrm{~A}$ & $0,36 \mathrm{~A}$ & $4,13 \mathrm{~B}$ & $11,73 \mathrm{~A}$ \\
Giovanna & $4,04 \mathrm{~B}$ & $0,39 \mathrm{~A}$ & $4,58 \mathrm{~A}$ & $11,85 \mathrm{~A}$ \\
Média & 4,11 & 0,37 & 4,35 & 11,79 \\
\hline CV $(\%)$ & 1,90 & 12,67 & 10,33 & 18,28 \\
\hline
\end{tabular}

"Médias seguidas da mesma letra na coluna não diferem entre si pelo teste de Tukey, ao nível de 5\% de probabilidade.

solúveis totais está ligado, especialmente, ao sabor do fruto. A maioria dos genótipos de tomate produz frutos com teor de sólidos solúveis variando de 5,0 a 7,0 ${ }^{\circ} \mathrm{Brix}$ (Ferreira et al., 2006). No presente experimento, os valores médios variaram de 4,07 a 4,68, nas diferentes porcentagens de sombreamento, e de 4,13 a 4,58 para os híbridos Dominador e Giovanna, respectivamente.

Os diferentes sombreamentos utilizados não influenciaram nas características de qualidade dos frutos do tomateiro; possivelmente, as diferenças apresentadas sejam devidas às características genéticas dos híbridos.

\section{CONCLUSÕES}

Os ambientes sombreados condicionaram melhor desempenho agronômico para o tomateiro tutorado no Norte de Minas Gerais, com destaque para a tela de 50\% de sombreamento que proporcionou maior produtividade total e comercial, além da maior altura das plantas.

O hibrido Dominador apresentou maior rendimento agronômico no Norte de Minas com maiores altura das plantas, número total de folhas, produtividades total e comercial de frutos.

O sombreamento das plantas não influenciou a qualidade dos frutos do tomateiro.

\section{AGRADECIMENTOS}

A UNIMONTES pelo apoio e a FAPEMIG pela concessão, ao primeiro autor, de bolsa de mestrado e, ao segundo autor, de Bolsa de Incentivo a Pesquisa e ao Desenvolvimento Tecnológico do Estado de Minas Gerais.

\section{REFERÊNCIAS}

Andriolo JL (2000) Fisiologia da produção de hortaliças em ambiente protegido. Horticultura Brasileira, 18:26-33.

Association of Official Agricultural Chemists - AOAC (1992) Official methods of analysis of the Association of the Agricultural Chemists. 12 $2^{\text {a }}$ ed. Washington, Arlington AOAC. 1115p.

Beckmann MZ, Duarte GRB, Paula VA, Mendez MEG \& Peil RMN (2006) Radiação solar em ambiente protegido cultivado com tomateiro nas estações verão-outono do Rio Grande do Sul. Ciência Rural, 36:86-92.
BRASIL (1995) Ministério da Agricultura, do Abastecimento e da Reforma Agrária. Portaria n ${ }^{\circ}$ 553, de 15 de setembro de 1995. Característica de identidade, qualidade, acondicionamento, embalagem e apresentação do tomate destinado ao consumo in natura. Diário Oficial da República Federativa do Brasil, Brasília, DF, 19 de setembro de 1995.

Caliman FRB, Silva DJH, Fontes PCR, Stringheta PC, Moreira GR \& Cardoso AA (2005) Avaliação de genótipos de tomateiro cultivados em ambiente protegido e em campo nas condições edafoclimáticas de Viçosa. Horticultura Brasileira, 23:255-259.

Carrijo AO, Vidal MC, Reis NVB, Souza RB \& Makishima N (2004) Produtividade do tomateiro em diferentes substratos e modelos de casas de vegetação. Horticultura Brasileira, 22:05-09.

Cockshull KE (1992) Crop environment. Acta Horticulturae, 34:77-85.

Empresa Brasileira de Pesquisa Agropecuária - Embrapa (1999) Sistema Brasileiro de Classificação de Solos. Brasília, Embrapa Produção de Informação. 412p.

Ferreira MMM, Ferreira GB, Fontes PCR \& Dantas JP (2006) Qualidade do tomate em função de doses de nitrogênio e da adubação orgânica em duas estações. Horticultura Brasileira, 24:141-145

Filgueira FAR (2005) Novo Manual de Olericultura: Agrotecnologia moderna na produção e comercialização de hortaliças. Viçosa, Editora UFV. 402p.

Fontes PCR \& Pereira PRG (2003) Nutrição mineral do tomate para mesa. Informe Agropecuário, 24:27-34.

Fontes PCR, Loures JL, Galvão JC, Cardoso AA \& Mantovani EC (2004) Produção e qualidade do tomate produzido em substrato, no campo e em ambiente protegido. Horticultura Brasileira, 22:614-619.

Goto R (1995) Manejo nutricional no cultivo de hortaliças em estufa. In: $9^{a}$ Encontro de Hortaliças, $6^{\circ}$ Encontro de Plasticultura da Região Sul, Maringá. Anais, Universidade Estadual de Maringá. p.11-18.

Gualberto R, Braz LT \& Banzatto DA (2002) Produtividade, adaptabilidade e estabilidade fenotípica de cultivares de tomateiro sob diferentes condições de ambiente. Pesquisa Agropecuária Brasileira, 37:81-88.

Instituto Brasileiro de Geografia e Estatística - IBGE (2011) Situação da produção e área de hortaliças no Brasil. Disponível em: <http://www.ibge.gov.br>. Acessado em: 17 de agosto de 2011.

Manrique LA (1993) Greenhouse crops: a review. Journal of Plant Nutrition, 16:2411-2477.

Nunes MUC \& Leal MLS (2001) Efeito da aplicação de biofertilizante e outros produtos químicos e biológicos, no controle da broca pequena do fruto e na produção do tomateiro tutorado em duas épocas de cultivo e dois sistemas de irrigação. Horticultura Brasileira, 19:156-160. 
Papadopoulos AP \& Hao X (1997) Effects of three greenhouse cover materials on tomato growth, productivity, and energy use. Scientia Horticulturae, 69:01-29.

Pereira ER (2002) Cultivo da rúcula e do rabanete sob túneis baixos cobertos com plástico com diferentes níveis de perfuração. Dissertação de Mestrado. Escola Superior de Agricultura "Luiz de Queiroz", Piracicaba. 113p.

Radin B, Bergamaschi H, Reisser Júnior C, Barni NA, Matzenauer $\mathrm{R}$ \& Didoné IA (2003) Eficiência de uso da radiação fotossinteticamente ativa pela cultura do tomateiro em diferentes ambientes Pesquisa Agropecuária Brasileira, 38:10171023.

Ribeiro AC, Guimarães PTG \& Alvarez V VH (1999) Recomendações para o uso de corretivos e fertilizantes em Minas Gerais $5^{\mathrm{a}}$ Aproximação. Viçosa, Comissão de Fertilidade do Solo do Estado de Minas Gerais. 359p.
Taiz L \& Zeiger E (2004) Fisiologia vegetal. $3^{\mathrm{a}}$ ed. Porto Alegre, Artmed. 719p.

Universidade Federal de Viçosa (2007) SAEG: Sistema para Análises Estatísticas e Genéticas. Versão 9.1. Viçosa, Fundação Arthur Bernardes. CD-ROM.

Varlet-Grancher C, Gosse G, Chartier M, Sinoquet H, Bonhomme R \& Allirand JM (1989) Mise au point: rayonnement solaire absorbé ou intercepté par un couvert végétal. Agronomie, 09:419-439.

Vida JB, Zambolim L, Vale FXR \& Costa H (2001) Manejo de doenças me cultivos protegidos. In: Zambolim L (Ed.) Manejo integrado, fitossanidade, cultivo protegido, pivô central e plantio direto. Viçosa, Suprema Gráfica e Editora Ltda. p.53-118. 